\title{
PERNIKAHAN LINTAS AGAMA DI KECAMATAN AEK NATAS KABUPATEN LABUHAN BATU UTARA PROVINSI SUMATERA UTARA
}

\author{
Siti Robiah
}

Mahasiswa Pascasarjana Prodi Hukum Islam LAIN Bukittinggi

e-mail:rrobiab@yahoo.co.id

DOI: http:/ / dx.doi.org/10.30983/islam_realitas.v2i2.189

\begin{tabular}{|c|c|c|}
\hline Diterima: 2 Oktober 2016 & Direvisi : 12 November 2016 & Diterbitkan: 20 Desember 2016 \\
\hline
\end{tabular}

\begin{abstract}
The background of writer to undertake this work is the incompatibility of wedding implementation which took place in the District Aek Natas Labuban Batu Utara regency. Implementation of their marriage were affected their marriage, because the purposes of marriage did not match the qualifying criteria of marriage and they tend to choose partners who has different beliefs with them. According to that, the writer wanted to know about the cross religion marriage that occurred in the district of Aek Natas. The form of the research is a field research using qualitative data, that a study based on the meaning contained in each of symptoms or existing events to collect data and analyze it on the fields. The source of data in this study are the perpetrators of marriage across religion, society, and community leaders concerned on research were called the key informants to assist authors in data gathering. In data gathering, the method that author used is observation and interview. From the research it can be concluded that the factors causing the interfaith marriage is due to a sense of love and affection, economic factors, promiscuity and the lack of religious education from parents to children, and the resulting the negative impact on the family such as a gap of the relationship, especially with parents, to feel isolated by their communities, the unrecorded marriage by the government, and according to the law of religion, the marriage is haram. The positive effect is the existence of religious tolerance in their households and increasing knowledge about different religious.
\end{abstract}

Keywords: Marriage, Interreligion Marriage.

\section{Abstrak}

Fenomena pernikahan yang terjadi di Kecamatan Aek Natas Kabupaten Labuhan Batu Utara yang mengakibatkan pengaruh yang berdampak pada pernikahan mereka, karena pernikahan yang mereka laksanakan tidak sesuai dengan kriteria syarat pernikahan dan mereka cenderung memilih pasangan yang berbeda keyakinan dengan mereka. Berdasarkan hal tersebut penulis ingin mengetahui tentang pernikahan lintas agama yang terjadi di Kecamatan Aek Natas. Dari penelitian yang penulis lakukan dapat diambil kesimpulan bahwa faktor penyebab pernikahan lintas agama adalah dikarenakan rasa cinta dan kasih sayang, faktor ekonomi, pergaulan bebas dan kurangnya pendidikan agama dari orang tua terhadap anak, dan mengakibatkan dampak dari pernikahan tersebut adalah dampak negatifnya yaitu terhadap keluarga terjadi kesenjangan dalam berhubungan dengan keluarga terutama orangtua, terhadap masyarakat merasa terisolasi dengan mereka, terhadap negara pernikahannya tidak diakui, dan terhadap agama hukum pernikahannya adalah haram. Dampak positifnya adalah adanya sikap toleransi dalam beragama dalam rumah tangga mereka dan bertambahnya ilmu tentang agama yang berlainan dengannya.

Kata Kunci: Pernikahan, Nikah Lintas agama.

\section{Latar Belakang}

Allah menciptakan makhlu permukaan bumi ini saling berpasangpasangan, termasuk di antaranya Allah menciptakan wanita sebagai pasangan untuk laki-laki yang akan menjadi sebuah ikatan yang dinamakan pernikahan, sebagai teman hidup sekarang atau untuk yang akan datang. 
Allah menciptakan pasangan tersebut dalam satu ikatan yang suci, yang dinamakan pernikahan. Yang akan menjadi tujuan pasangan antara laki-laki dengan perempuan yang telah pantas untuk menikah dan memenuhi kriteria pernikahan tersebut. ${ }^{1}$

Namun yang menjadi permasalahan disini yaitu fenomena tentang pernikahan beda agama mulai menjadi populer di kalangan masyarakat, terutama di zaman modern ini, yang dimaksud dengan beda agama disini adalah perempuan muslimah dengan laki-laki non Muslim dan sebaliknya laki-laki Muslim dengan wanita non Muslim. ${ }^{2}$ Dalam istilah fikih disebut kawin dengan orang kafir. ${ }^{3}$

Yang dinyatakan Allah dalam surat alBaqarah Ayat 221:

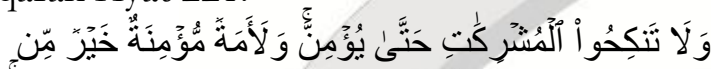

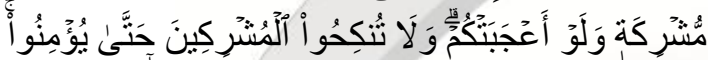

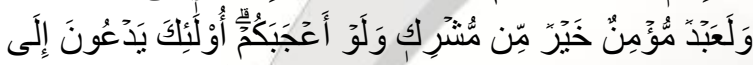



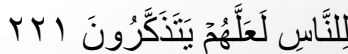

Artinya: Dan janganlah kamu menikahi wanita-wanita musyrik, sebelum mereka beriman. Sesungguhnya wanita budak yang mukmin lebih baik dari wanita musyrik, walaupun Dia menarik hatimu. dan janganlah kamu menikahkan orangorang musyrik (dengan wanita-wanita mukmin) sebelum mereka beriman. Sesungguhnya budak yang mukmin lebih baik dari orang musyrik, walaupun Dia menarik hatimu. mereka mengajak ke neraka, sedang Allah mengajak ke surga dan ampunan dengan izin-Nya. dan Allah menerangkan ayat-ayat-Nya (perintah-perintah-Nya) kepada manusia supaya mereka mengambil pelajaran.

1 Abdul Rahman Ghazaly, Figh Munakahat (Jakarta: PT. Grafindo Persada), h. 59.

2 Amir Syarifuddin, Hukum Perkawinan Islam di Indonesia (Jakarta: Prenada Kencana Group. 2009), h. 133.

${ }^{3}$ Sayyid Sabiq, Fikih Sunnah Jilid 6 (Bandung: PT Alma'rif, 1980), h.152.
Ayat ini menunjukkan keberagamaan yakni Islam menjadi syarat dalam memilih pasangan.Karena keberagamaan merupakan fondasi bangunan rumah tangga. Fondasi yang kokoh tidak ditentukan oleh kecantikan, harta, status sosial, dan sebagainya, Karena semua itu mudah pudar dan lenyap. Fondasi yang kuat adalah agama. ${ }^{4}$

Dalam Jamil, menurut hukum di negara Indonesia pernikahan beda agama telah diatur dalam Kompalasi Hukum Islam tentang larangan perkawinan beda agama pasal 40 bahwa: Dilarang melangsungkan perkawinan antara seorang pria dan wanita, karena wanita tersebut tidak beragama Islam. Pada pasal 44 dinyatakan bahwa: seorang wanita Islam dilarang melangsungkan perkawinan dengan seorang pria yang tidak beragama Islam ${ }^{5}$.

Adapun pernikahan di Kec.Aek Natas Kab. Labuhan Batu Utara Prov. Sumatera Utara sebagian kecil masyarakat di sini sebagian kecil memilih untuk menikah dengan laki-laki yang berbeda keyakinan dengan mereka, tanpa mempertimbangkan resiko yang akan terjadi jika pernikahan tersebut dilanjutkan akan lebih banyak menimbulkan keburukan dari pada kebaikan, hingga saat ini ada sekitar 13 orang yang melakukan pernikahan beda agama saat melakukan observasi. Mereka cenderung tidak ingin mendengar pendapat orang lain dan lebih memilih keputusan sendiri walaupun keputusan tersebut bertentangan dengan agama Islam. Singkatnya mereka tidak menghiraukan apa yang dilarang oleh agama, masyarakat setempat dan bahkan mengabaikan nasihat orang tua mereka sendiri.

Berdasarkan fenomena di atas permasalahan yang hendak penulis bahas adalah proses pernikahan lintas agama di 2006), h.62.

${ }^{4}$ Shafra, Fikih Munakahat (Bukittinggi: STAIN,

5 Jamil, M. Mukhsin, "Revitalisasi Islam Kultural", Walisongo: Jurnal Penelitian Sosial Keagamaan, 21.2, 2013, h. 271-308. 
Kecamatan Aek Natas Kabupaten Labuhan Batu Utara Provinsi Sumatera Utara. Praktek pernikahan semacam ini dalam berbeda dengan yang terdapat dalam ayat dan praktek penikahan yang berlaku secara umum dalam kalangan agama Islam ${ }^{6}$. Namun demikian, dilihat dari aspek tujuan pernikahan itu sendiri telah terabaikan..

\section{Pernikahan Lintas Agama dalam Kerangka Teoritis}

Dalam Rahmaniah dan Rahman yang dimaksud dengan pernikahan lintas agama adalah pernikahan yang dilaksanakan oleh dua orang antara seorang laki-laki dengan seorang perempuan yang berlainan agama dari yang diyakini mereka. Atau pernikahan seorang wanita yang beragama Islam dengan seorang laki-laki yang beragama non Islam atau sebaliknya ${ }^{7}$.

\section{Pengertian Pernikahan}

Pernikahan atau perkawinan dalam literatur fikih berbahasa Arab disebut dengan dua kata, yaitu nikah (نكاح) dan zawaj (زواج). Kedua kata ini yang terpakai dalam kehidupan sehari-hari orang Arab banyak terdapat dalam al-Quran dan Hadits Nabi SAW. ${ }^{8}$ Definisi pernikahan dalam Kompilasi Hukum Islam (KHI) yang merumuskan sebagai berikut: "Perkawinan menurut hukum Islam adalah pernikahan, yaitu akad yang sangat kuat atau mitsaqan ghalizhan untuk mentaati perintah

${ }^{6}$ Syahr, Zulfia Hanum Alfi, "Wasiat Wajibah sebagai Wujud Penyelesaian Perkara Waris Beda Agama dalam Perkembangan Sosial Masyarakat", Holistik, 1.2, 2016, h. 123-133.

${ }^{7}$ Rahmaniah, Syarifah Ema, "Multikulturalisme dan Hegemoni Politik Pernikahan Endogami: Implikasi dalam Dakwah Islam", Walisongo: Jurnal Penelitian Sosial Keagamaan, 22. 2, 2014, h. 433-456. Bandingkan dengan Rahman, Yusuf, "Pengantar Redaksi", Journal Of Qur'an And Hadith Studies, 1.1, 2012, h 1-2.

${ }^{8}$ Amir Syarifuddin, Hukum Perkawinan Islam di Indonesia Antara Figh Munakahat dan Undang-Undang Perkawinan (Jakarta: Kencana Prenada Media Croup, 2009), h. 35.
Allah dan melaksanakannya merupakan ibadah. ${ }^{9}$

Undang-Undang Republik Indonesia Nomor 1 tahun 1974 Tentang Perkawinan, dan Instruksi Presiden Nomor 1 Tahun 1991 Tentang Kompilasi Hukum Islam yang merumuskan demikian: "Perkawinan ialah ikatan lahir batin antara seorang pria dengan seorang wanita sebagai suami isteri dengan tujuanmembentuk keluarga (rumah tangga) yang bahagia dan kekal berdasarkan Ketuhanan Yang Maha Esa". ${ }^{10}$

\section{Hukum Pernikahan}

Segolongan fuqaha', yakni jumhur (mayoritas ulama) berpendapat bahwa nikah itu hukumnya sunnah. Golongan Zhahiriyah berpendapat bahwa nikah itu wajib. ${ }^{11}$ Dasar dari pendapat ulama Zhahiriyah ini adalah perintah Allah dan Rasul yang begitu banyak untuk melangsungkan pernikahan. Hukum menikah dihat dari segi kondisi orang yang melaksanakan serta tujuan melaksanakannya, di antaranya adalah; a) Melakukan pernikahan hukumnya wajib. Bagi orang yang telah mempunyai kemauan dan kemampuan untuk menikah dan dikhawatirkan akan tergelincir pada perbuatan zina, seandainya tidak menikah maka hukum melakukan pernikahan bagi orang-orang tersebut adalah wajib; b) Melakukan pernikahan yang hukumnya Sunnat. Orang yang telah mempunyai kemauan dan kemampuan untuk melangsungkan pernikahan, tapi kalau tidak menikah tidak dikhawatirkan akan berbuat zina, maka hukum melakukan pernikahan bagi orang tersebut adalah sunnat. ${ }^{12}$ c) Melakukan pernikahan yang hukumnya haram. Bagi orang

${ }^{9}$ Tim, Kompilasi Hukum Islam (Bandung: Fukus Media, 2012)

1.

${ }^{10}$ Undang-Undang Nomor 1 Tahun 1974, Pasal

${ }^{11}$ Abdul Rahman Ghozali, Fiqh Munakahat,..., h. 16.

12 Abdul Rahman Ghozali, Figh Munakahat,..., h. 19-20 
yang tidak mempunyai keinginan dan tidak mempunyai kemampuan serta tanggung jawab untuk melaksanakan kewajiban-kewajiban dalam rumah tangga sehingga apabila melangsungkan pernikahan akan terlantar dirinya dan isterinya, maka hukum melakukan pernikahan tersebut adalah haram. ${ }^{13}$ d) Melakukan pernikahan yang hukumnya Makruh. Menurut pendapat Abdul Rahman Ghazali makruh menikah bagi orang yang mempunyai kemampuan dan dapat menahan diri sehingga tidak memungkinkan dirinya tergelincir berbuat zina sekiranya tidak menikah. Hanya saja orang ini tidak mempunyai keinginan yang kuat untuk dapat memenuhi kewajiban suami istri dengan baik. ${ }^{14}$

e) Melakukan pernikahan yang hukumnya mubah. Bagi orang yang mempunyai kemampuan untuk melakukannya, tetapi apabila tidak melakukannya tidak khawatir akan berbuat zina dan apabila tidak menikah juga tidak akan menelantarkan isteri. Hukum mubah ini ditujukan bagi orang yang antara pendorong dan penghambatnya untuk menikah itu sama, sehingga menimbulkan keraguan orang yang akan melakukan pernikahan, seperti mempunyai keinginan tapi belum mempunyai kemampuan, mempunyai kemampuan tapi belum mempunyai kemuan yang kuat. ${ }^{15}$

\section{Rukun dan Syarat Pernikahan}

Terdapat beberapa rukun dan syarat akad nikah, yaitu; 1) Akad adalah perjanjian yang berlangsung antara dua pihak yang melangsungkan pernikahan dalam bentuk ijab dan qabul. Ijab adalah penyerahan dari pihak pertama, sedangkan qabul penerimaan dari

20.

${ }^{13}$ Abdul Rahman Ghozali, Fiqh Munakahat,..., h.

21.

${ }^{14}$ Abdul Rahman Ghozali, Fiqh Munakahat,..., h.

22. pihak kedua. ${ }^{16}$ 2) Laki-laki dan perempuan yang menikah. Islam hanya mengakui pernikahan antara laki-laki dan perempuan dan tidak boleh lain dari itu, seperti sesama lakilaki atau sesama perempuan karena ini yang tersebut dalam al-Quran. 3) Wali dalam pernikahan. Wali dalam pernikahan adalah seorang yang bertindak atas nama mempelai perempuan dalam melakukan suatu akad nikah. Akad nikah yang dilakukan oleh dua pihak, yaitu puhak laki-laki yang dilakukan oleh mempelai laki-laki itu sendiri dan pihak perempuan yang dilakukan oleh walinya. ${ }^{17} 4$ ) Saksi. Akad pernikahan mesti disaksikan oleh dua orang saksi supaya ada kepastian hukum dan untuk menghindari timbulnya sanggahan dari pihak-pihak yang berakad di belakang hari.

\section{Pernikahan Lintas Agama Dalam Pandangan Islam}

\section{Menikah dengan Orang Musyrik}

Imam al-Thabari dalam Zada mengatakan dalam tafsirnya, yakni Allah telah mengharamkan terhadap wanita-wanita mukminah untuk menikahi laki-laki musyrik, dalam bentuk bagaimanapun kemusyrikannya dan dari golongan musyrik manapun ia. Maka janganlah engkau wahai orang-orang mukmin, menikahkan mereka dengan orang-orang musyrik itu ${ }^{18}$. Sebab yang demikian itu haram untuk kamu lakukan. Lebih baik bagi kamu menikahkan mereka dengan hamba sahaya yang hitam asalkan beriman, yang membenarkan Allah dan Rasul-Nya dan ajaran-ajaran yang datang dari sisi-Nya, dari pada kamu menikahkan mereka dengan

16 Amir Syarifuddin, Hukum Perkawinan Islam di Indonesia Antara Figh Munakahat dan Undang-Undang Perkawinan,..., h. 61.

${ }^{17}$ Amir Syarifuddin, Hukum Perkawinan Islam di Indonesia Antara Figh Munakahat dan Undang-Undang Perkawinan..., h. 69.

18 Zada, Khamami, "Arus Utama Perdebatan Hukum Perkawinan Beda Agama", Abkam: Jurnal Ilmu Syariah, 13.1, 2013, h. 45 
seorang merdeka yang musyrik walaupun mereka memiliki nasab dari kalangan orangorang terpandang, atau walaupun harta yang mereka miliki membuatmu terkagum-kagum. ${ }^{19}$ Sebab khawatir merusak agamanya.

Imam Ath-Thabari melanjutkan, janganlah engkau mengikuti dari apa yang mereka katakan. Janganlah kalian menikahi mereka dan jangan menikahkan seseorang dengan mereka. Sebab mereka tidak hentihentinya akan mendatangkan kemudharatan bagimu. $^{20}$

\section{Menikah dengan Abli Kitab}

Dalam buku karangan Dr. Abd. Rachman Assegaf perkawinan campuran adalah perkawinan yang terjadi antar pihakpihak yang berbeda agama, yakni Muslim (baik laki-laki maupun wanita) dengan non-Muslim. Istilah non-Muslim di bedakan dalan dua kategori; yaitu, a) Ahli Kitab; b) Bukan Ahli Kitab. Keduanya berbeda dalam sudut pandangan hukum, dan masing-masing kategori juga terdapat perbedaan pendapat di kalangan ulama. ${ }^{21}$

Berikut ini masalah laki-laki Muslim kawin dengan wanita Ahli kitab. Para ulama berbeda pendapat mengenai hukum perkawinan laki-laki Muslim dengan wanita ahli kitab. Menurut jumbur (mayoritas) ulama, baik Imam Malik, Abu Hanafi, asy-Syafi'i, maupun Ahmad ibn Hanbal, atau kalangan Sunni, seorang laki-laki Muslim diperbolehkan menikah dengan wanita Ahli kitab yang berada dalam lindungan atau kekuasaan negara Islam (abli dzimmah). ${ }^{22}$

${ }^{19}$ Syaikh Imad Zaki Al-Barudi dan Penerjemah Samson Rahman, Tafsir Wanita, (Kairo Mesir, Jakarta Timur: al-Maktabah at-Taufiqiyah, Pustaka al-Kautsar. 2010), h. 41

${ }^{20}$ Syaikh Imad Zaki Al-Barudi dan Penerjemah Samson Rahman, Tafsir Wanita..., h. 43.

${ }^{21}$ Abdul Rachman Assegaf, Studi Islam Kontekstual Elaborasi Paradigma Baru Muslim Kaffah, (Yogyakarta: Gama Media, 2005), h. 141.

${ }^{22}$ Abdul Rachman Assegaf, Studi Islam Kontekstual Elaborasi Paradigma Baru Muslim Kaffah,..., h. 141.
Allah mengharamkan menikahkan seorang Muslimah dengan seorang kafir dan membolehkan seorang Mukmin menikah dengan wanita Ahli kitab padahal mereka juga termasuk bagian dari orang-orang kafir karena:

Sesungguhnya agama Islam itu tinggi dan tidak akan ada Agama yang lebih tinggi darinya. Sedangkan kendali keluarga itu berada di tangan seorang suami, karena ia seorang lelaki. Walaupun antara keduanya memiliki kesamaan dalam akad, namun hal itu tidak akan menafikan perbedaan yang ada diantara keduanya, sebgaimana dalam kepemilikan budak.

Menikah dengan Shabiun dan Majusi

Para ulama berpendapat bahwa shabiun adalah orang-orang menganut ajaran Zoroaster (Majusi), Yahidi, dan Nasrani, bukan menganut agama tertentu. Seorang pioner ulama tauhid, mujahid, mengenai mereka sebagai ahli kitab yang membaca kitab Zabur. Sedangkan ulama ilmu kalam yang lain, Hasan, mengatakan bahwa kaum shabiin adalah mereka yang menyembah dewa-dewa. ${ }^{23}$

Menurut Ibnu Katsir, mufasir yang masyhur, bahwa orang-orang Shabiun ini biasa melakukan sembahyang menghadap arah yang berlawanan dengan kiblat, mereka juga membaca Kitab Zabur dan menyembah dewadewa. Mereka mengenal Allah, mempunyai syari'ah sendiri, serta tinggal menetap di Irak. Dikatakan juga bahwa mereka mempercayai beberapa nabi, berpuasa selama 30 hari dalam satu tahun, bahkan mereka sembahyang lima kali sehari semalam. ${ }^{24}$

Di dalam undang-undang perkawinan mengatur juga tentang perkawinan beda agama yang disebut dengan perkawinan campuran, sebagaimana disebutkan dalam pasal 57 sampai dengan pasal 62.

23 A. Rahman I. Doi, Penjelasan Lengkap HukumHukum Allah (Syariab)..., h. 180.

24 A. Rahman I. Doi, Penjelasan Lengkap HukumHukum Allah (Syariab)..., h. 181. 
Menurut di dalam Pasal 57 Undangundang Perkawinan: Yang dimaksud dengan perkawinan campuran dalam Undang-undang ini ialah perkawinana antara dua orang yang di Indonesia tunduk pada hukum yan berlainan, karena perbedaan kewarganegaraan dan salah satu pihak kewarganegaraan Indonesia ${ }^{25}$.

Adapun yang di maksud dengan hukum yang berlainan adalah disebabkan karena perbedaan kawarganegaraan, tempat, golongan, dan agama. ${ }^{26}$

Dalam rancangan undang-undang menurut juga dijelaskan pernikahan antar agama yang disinggung dalam pasal 11 ayat 2 yaitu, seperti antara laki-laki Islam atau wanita Islam di satu pihak dengan wanita bukan Islam atau laki-laki bukan Islam di lain pihak, adalah haram (terlarang) menurut ketetapan Tuhan Yang Maha Esa dalam QS. 2:221. Segala pihak yang bukan Islam dinamakan oleh Allah dalam ayat tersebut dengan Istilah musyrik dan musyrikah ${ }^{27}$.

Lain istilah yang dipergunakan dalam alQuran terhadap pihak yang bukan Islam ialah kufur dan kawafir dan musyrikah adalah "setali tiga uang”. Dalam QS. 60:10 itu dengan tegas dinyatakan bahwa perempuan Islam tidak boleh di kawinkan dengan laki-laki kafir, demikian pula tidak dibolehkan laki-laki Islam mengawini perempuan yang kafir, malahan seorang laki-laki Islam yang memasuki Agama Islam sedangkan istrinya tetap mau tinggal pada agama asalnya (yaitu Agama kafir) wajib menceraikan isterinya itu. ${ }^{28}$

25 Wahyuni, Sri, "Perkawinan Beda Agama dalam Perspektif Agama-agama", Jurnal Essensia. Yogyakarta: Fakultas Ushuluddin, UIN Sunan Kalijaga, 3, 2, 2005, h. 12

26 K. Wantjik Saleh, Hukum Perkawinan Indonesia..., h. 46.

${ }^{27}$ Wahyuni, Sri, "Politik Hukum Perkawinan dan Perkawinan Beda Agama di Indonesia", Jurnal Pusaka, 1.2, 2014, h. 76.

28 Sudarsono, Hukum Kekeluargaan Nasional (Jakarta: PT. Rineka Cipta, 1991), h. 28.

\section{Metodologi Penelitian}

Dalam penyusunan penelitian ini, penulis melakukan metode penelitian secara kualitatif. Yang dimaksud dengan metode kualitatif adalah penelitian yang melihat keadaan-keadaan, gejala atau suatu peristiwa yang ada di tengah-tengah masyarakat yang berkaitan dengan hal-hal yang akan diteliti untuk memperoleh suatu kesimpulan. ${ }^{29}$

Penelitian yang penulis pakai untuk karya ilmiah ini adalah menggunakan penelitian lapangan (field research), yang merupakan studi kasus yaitu pengumpulkan data langsung dari lokasi penelitian. ${ }^{30}$ Maka, penelitian lapangan dengan pendekatan kualitatif ini dianggap sengat tepat untuk meneliti masalah ini.

Lokasi penelitian ini adalah di Kec. Aek Natas Kab. Labuhan Batu Utara Prov. Sumatera Utara. Dengan alasan di Kecamatan tersebut sebahagian praktek pernikahan berbeda dengan yang terdapat di dalam ayatayat Allah dan praktek yang berlaku secara umum.

Adapun teknik pengumpulan data dilakukan dengan beberapa tekhnik; a) Observasi. Observasi merupakan salah satu teknik pengumpulan data yang digunakan dalam penelitian kualitatif. ${ }^{31}$ Dengan observasi dapat kita peroleh gambaran yang lebih jelas tentang kehidupan sosial, yang sukar diperoleh dengan metode lain. ${ }^{32}$ b) Wawancara. Wawancara merupakan pertemuan dua orang untuk bertukar informasi dan ide melalui Tanya jawab. ${ }^{33}$ Wawancara atau interviu adalah suatu bentuk komunikasi percakapan yang

\footnotetext{
${ }^{29}$ Burhan Bugin, Analisa Data Penelitian Kualitatif (Jakarta: PT. Raja Grafindo Persada, 2003), h. 90.

30 Burhan Bugin, Analisa Data Penelitian Kualitatif..., h. 90-91.

31 Beni Ahmad Saebani, Metode Penelitian (Bandung: Pustaka Setia,2008), h, 186.

32 S. Nasution, Metode Research (Penelitian Ilmiah) (Jakarta: Bumi Aksara,2007), h.106.

33 Beni Ahmad, Metode Penelitian (Bandung: Pustaka Setia,2008), h.190.
} 
bertujuan memperoleh informasi. ${ }^{34}$ Pewawancara disebut intervieuwer, sedangkan orang yang diwawancarai disebut Interviewee. ${ }^{35}$ Adapun bentuk pertanyaan yang penulis gunakan dalam wawancara ini adalah wawancara terbuka yaitu wawancara yang menggunakan kuisioner terbuka, yang memberikan keluasan bagi responden untuk memberikan jawaban dengan bebas tanpa dibatasi oleh alternatif jawaban yang dibatasi.

Adapun informan adalah orang yang di jadikan sebagai sumber informasi tentang situasi atau kondisi latar penelitian. ${ }^{36}$ Sedangkan analisis data adalah suatu kegiatan yang dilakukan untuk mencari, menyusun, secara sistematis, sehingga mudah dipahami dan bisa dibuat kesimpulan pada data yang didapatkan.

\section{Pernikahan Lintas Agama di Kecamatan Aek Natas}

Berdasarkan hasil wawancara penulis dengan beberapa orang yang melakukan pernikahan lintas agama mengatakan bahwa, faktor mereka malakukan pernikahan lintas agama adalah bahwa cinta dan pilihan hidup merupakan hak seseorang yang hanya dimiliki dan ditentukan masing-masing orang yang bersangkutan.

Dari hasil penelitian penulis bahwa faktor penyebab pernikahan lintas agama adalah karena faktor rasa cinta dan kasih sayangnya kepada pasangan yang dibinanya sejak awal mereka berpacaran, hingga mereka menikah. Dan mereka menjadikan rasa cinta sebagai dasar mereka melakukan pernikahan lintas agama, dan menjadikan rasa cinta sebagai alat pembenar.

Dan faktor selanjutnya adalah faktor ekonomi yang mana pada saat sekarang ini

34 S. Nasution, Metode Research (Penelitian Ilmiab) (Jakarta: Bumi Aksara, 2007), h.113.

35 Husaini Usman\& Purnomo Setiady Akbar, Metodologi Penelitian Sosial (Bandung: Bumi Aksara, 2006) cet, 6, h. 58 .

${ }^{36}$ Sukardi, Metodologi Penelitian Pendidikan (Jakarta : Bumi Aksara, 2003), h. 90. bahwa dikarenakan ekonomi semakin sulit maka demi kebutuhan itu mereka mau menikah dengan orang yang berlainan keyakinan dengannya.

Dan faktor yang terakhir adalah kurangnya didikan Agama Islam kepada anakanaknya hingga anaka kurang mengetahui hakikat dari Agama Islam, yang mana harus di kerjakan dan yang mana harus ditinggalkan.

Dan lebih jelasnya pada penjelasan pernikahan lintas agama ini penulis mengemukakan bahwa apabila terjadi pernikahan seorang pria Muslim dengan seorang wanita non Muslim, menurut Sayyid Sabiq dalam bukunya "Fiqih Sunnah", ulama fikih sepakat melarang dan mengharamkan pernikahan beda agama ini, sebagaimana firman Allah dalam surat al-Baqarah Ayat 221.

Menurut mereka, pernikahan yang dilakukannya adalah atas kemauan sendiri dan dia mengatakan bahwa penyebab ia mau menikah dengan orang yang berbeda keyakinan dengannya dikarenakan faktor ekonomi dan dia juga mengatakan tidak mau hidup susah. Dengan suaminya yang sekarang merasa bahagia karena mempunyai kehidupan yang berkecukupan.

Pernikahan lintas agama seperti ini menurut Palandi, adalah boleh dengan alasan bahwa pernikahan merupakan hak seseorang dalam memilih pasangan hidup mereka, yang penting apa yang menurut mereka cocok maka hak mereka untuk melaksanakan pernikahan tersebut. Sama seperti yang dikatakan kebanyakan dari mereka yang melakukan pernikahan lintas agama ${ }^{37}$.

Pernikahan lintas agama yang mereka lakukan mempunyai tujuan yaitu sebagai suami istri agar mereka dapat bersama-sama berkolaborasi untuk membuat sesuatu yang lebih baik dan bermanfaat juga bagi orang lain.

37 Palandi, Anggreini Carolina, "Analisa Yuridis Perkawinan Beda Agama di Indonesia", Lex Privatum, 1.2, 2013, h. 32. 
Perkataan ini tulus dari hati kami berdua ucap mereka

Pernikahan lintas agana yang dilakukan para responden pada umumnya adalah atas kemauan sendiri dengan alasan hak asasi manusia dan atas dasar cinta dan saling suka sama suka. Walaupun banyak para pihak yang menantang dengan pernikahan mereka terutama kedua orang tua mereka, namun mereka tidak pernah menghiraukan yang demikian itu.

Dari sejak awal mereka menjalin cinta memang ada perasaan gundah. Bukan karena gundah perasaan sayangnya kepada pasangannya itu, tapi soal bagaimana keluarga mereka bisa menerima dan merasakan kasih sayang mereka. Dari sisi agama masing-masing sebagian ada yang menganut agama yang ketat dan sebagian memang karena kurangnya pendidikan agama dari keluarga terutama dari kedua orang tua. Seperti kata pepatah asam digunung garam dilaut bertemu juga di belanga.

Pernikahan mereka tidak disaksikan oleh pihak-pihak keluarga terdekat masing-masing. Pernikahan mereka adalah sebuah pengalaman batin yang penuh cerita suka dan duka. Bukan hanya menyangkut soal agama, masalah cinta dan keluarga tapi juga menyangkut soal hubungannya dengan birokrasi agama dan juga birokrasi pencatatan pernikahan yang aturannya dikenal sangat berbelit-belit dalam merespons dan menanggapi niat suci anak manusia yang ingin menikah.

Bagi yang kokoh agamanya masingmasing berpegang teguh kepada kitabnya."Dari hati kami yang paling dalam dengan tulus saya bisa merasakan langkah ini adalah langkah hidup saya yang akan saya jalani bersama suami saya. Ketulusan itu hanya bisa muncul setelah semangat spiritual dapat terasa dengan keterbukaan dan keikhlasan". Sesuai dengan studi Hutapea yang menjelaskan bahwa mereka berdua sanggup menghadapi perbedaan dengan rasa cinta dan kasih sayang yang tulus dan hanya menjadikan hanya sekedar perbedaan yang biasa ${ }^{38}$.

Dengan demikian, upaya melangsungkan pernikahan beda agama yaitu dengan tiga caranya, yaitu; 1) Melalui cara Islam, yaitu dengan melangsungkan akad; 2) Melalui pemberkatan di gereja; 3) Melalui pencatatan sipil di kantor catatan sipil.

\section{Dampak Dari Pernikahan Lintas Agama}

Dalam bagian ini akan dikaji dari sisi dampak pernikahan beda agama dam keberagamaan keluarga, terlebih khusus terkait dengan pendidikan agama otang tua terhadap anak. Berdasarkan kajian Mallarangan, yang diperoleh kedua hak tersebut sangat terkait dengan kekuatan agama masing-masing pihak suami maupun istri dalam beragama, serta didikan agama untuk anak. 1) Kalau kedua orang tuanya sama-sama tidak kuat dalam beragama, maka pendidikan agama pada anak sedikit longgar, kalu kemuadian anak lebih taat dengan memeluk salah satu agama tertentu, maka itu lebih dipengaruhi oleh keadaan lingkungan sekitar. 2) Kalau salah satu pasangan lebih kuat dalam beragama, maka pendidikan pada anak dalam agama cenderung kepada agama yang dominan dalam rumah tersebut, dan pengetahuan anak dalam agama yang lain juga cenderung rendah. Maka anak juga akan otomatis mengikut kepada agama yang lebih kuat di dalam keluarga tersebut. 3) Kalau pasangan suami istri sama-sama kuat dalam beragama, ada dua model yang termasuk dalam kelompok ini ${ }^{39}$. Dalam Ashsubli, pasangan yang ketika akan menikah mempunyai kesepakatan tertentu mengenai

38 Hutapea, Bonar, "Dinamika Penyesuaian Suami-Istri dalam Perkawinan Berbeda Agama (the Dynamics of Marital Adjustment in the Interfaith Marriage)", Sosiokonsepsia: Jurnal Penelitian dan Pengembangan Kesejabteraan Sosial, 16.01, 2011, h. 123-145

${ }^{39}$ Mallarangan, Hilal, "Pembaruan Hukum Islam dalam Hukum Keluarga di Indonesia", Hunafa: Jurnal Studia Islamika, 5.1, 2008, h. 37-44. 
kehidupan keluarga nantinya, khususnya dalam pendidikan agama pada anak dalam artian mempunyai perjanjian dalam keberagamaan pada anak. Faktor lainnya, belum ada kesepakatan atau perjanjian dalam agama anak nantinya dan anak diberikan kebebasan nantinya dalam memilih agama ${ }^{40}$.

Menurut tokoh masyarakat yang penulis wawancarai bahwa dampak dari pernikahan lintas agama sangat berpengaruh pada anak, anak dididik mengikut kapada agama yang mana semuanya tergantung kepada didikan kedua orang tuanya.

Dalam pernikahan lintas agama menurut Sembiring ada terlihat dari sisi positif dan negatifnya, yaitu, 1) dalam aspek positif adalah toleransi, dalam keluarga pasangan beda agama, agama dianggap tidak layak diajukan sebagai sumber konflik, keluarga lebih menginginkaan perdamaian dirumah, sehinnga perbedaan agama tidak berguna untuk di besar-besarkan, toleransi merupakan aspek paling positif; 2) dalam aspek negatif adalah kompetisi terselubung, masing-masing orang tua dalam hati kecilnya menginginkan kalau anak nantinya mengikuti agama dirinya. Keinginan ini membuat masing-masing orang tua berusaha menarik anaknya kedalam agamanya ${ }^{41}$.

Berkaitan dengan dampak dari pernikahan lintas agama ini bagi mereka yang pasangan suami istri ada beberapa dampaknya, karena menurut Wahyuni, dalam Islam pernikahan beda agama tidaklah sah maka akan berdampak juga sebagai berikut: 1) Hubungan suami istri tidaklah sah dan diangggap layaknya berzina; 2) Pertalian Nasab

40 Ashsubli, Muhammad, "Undang-Undang Perkawinan dalam Pluralitas Hukum Agama (Judicial Review Pasal Perkawinan Beda Agama)", Jurnal Cita Hukum, 3.2, 2015, h. 67

41 Sembiring, Elsaninta, dan Vanny Christina, "Kedudukan Hukum Perkawinan Adat di dalam Sistem Hukum Perkawinan Nasional Menurut UU No. 1 Tahun 1974", Parental, 1.4, 2014, h. 156 anak dengan ayah kandungnya terputus, ayah biologisnya juga tidak diakui sebagai walinya karena nasabnya terputus; 3) Hukum nafkah bagi ayah kandungnya juga tidak ada; 4) Antara anak dan ayah tidak ada hubungan saling mewarisi; 5) Jika ayahnya menjadi wali anaknya yang merupakan hasil dari nikah beda agama, maka status kewaliannya tidak sah dan pernikahan anak itu juga tidah $\mathrm{sah}^{42}$.

Dari keterangan yang disampaikan oleh tokoh masyarakat di atas menurut penulis bahwasanya dampak dari pernikahan lintas agama ini sangat buruk hingga selama mereka melakukan hubungan sebagai suami istri dianggap berzina dan pengaruhnya juga hingga ke anak dan keturunan mereka.

\section{Kesimpulan}

Perkawinan lintas agama adalah perkawinan antar agama, yaitu perkawinan yang dilakukan oleh seorang pria atau seorang wanita yang beragama Islam dengan seorang pria atau seorang wanita yang beragama non Muslim, pernikahan lintas agama ini terjadi jika calon istri beragama Islam, sedangkan calon suami tidak beragama Islam, baik Ahli Kitab maupun musyrik dan calom suami beragama Islam sedangkan calon istri beragama non Islam, baik Ahli kitab maupun orang musyrik maka hukum pernikahan mereka adalah haram, sesuai dengan surat al-Baqarah ayat 221.

Dari hasil wawancara ke beberapa responden kebanyakan motivasi menikah karena dilandasi oleh rasa cinta satu sama lain, walaupun ditentang oleh kedua orang tua mereka dan menunjukkan 6 kasus pernikahan dilaksanakan di KUA dan 2 kasus dilaksanakan

42 Wahyuni, Sri, "Kontroversi Perkawinan Beda Agama di Indonesia", Jurnal Hukum Islam IAIN Pekalongan, 13.1, 2011, h. 32. Lihat juga Nofiardi, Nofiardi, and Syafwan Rozi, "Penerapan Nilai Toleransi Antar Budaya dalam Pelaksanaan Hukum Kewarisan Islam pada Masyarakat Perbatasan di Rao Pasaman Sumatera Barat", Ijtihad: Jurnal Wacana Hukum Islam dan Kemanusiaan, 17.1, 2017, h. 46 
di kantor catatan sipil dan semuanya terjadi di dalam negeri. Ada tiga variasi interaksi keagamaan pasangan beda agama yaitu; 1) Pasangan yang beda agama kurang kuat dalam beragama. Kelompok orang ini adalah termasuk bagian kelompok orang yang menganggap agama itu sesuatu yang bisa dipakai atau tidak, biasa disesuaikan dengan kepentingan adaministratif pemerintah, seperti dalam pengurusan KTP dan sebagainya. 2) Pasangan di mana salah satu pasangan adalah yang lebih kuat dalam beragama. Pasangan yang termasuk dalam jenis ini adalah di mana salah satu suami atau istri lebik kuat dan ingin berperan dalam membawa agamanya. Sementara pasangan yang lain tidak terlalu memungsikan agamanya. Dalam keadaan demikian, karena dominasi agama salah satu pasangan maka terjadi kemudian adalah suasana rumah cenderung mengarah pada agama tersebut. 3) Pasangan yang sama-sama kuat dalam beragama. Mereka masing-masing mempertahankan agama sendiri dan masingmasing saling menghargai agama yang dianut suami isteri tersebut. Model pasangan ini adalah ketika menikah mempunyai kesepakata tertentu mengenai kehidupan keluarganya, termasuk dalam beragama.

\section{Daftar Pustaka}

\section{Buku Teks}

Ahmed, Abdul A'la al-Maudidi dan Fazl, Pedoman Perkawinan Dalam Islam (Jakarta: Darul Ulum Press, 1994).

Al-Barudi, Imad Zaki dan Penerjemah Rahman, Samson, Tafsir Wanita (Jakarta Timur: al-Maktabah atTaufiqiyah, Pustaka al-Kautsar, 2010)

Assegaf, Abdul Rachman, Studi Islam Kontekstual Elaborasi Paradigma Baru Muslim Kaffah (Yogyakarta: Gama Media, 2005).
Bugin, Burhan, Analisis Data Penelitian Kualitatif (Jakarta: PT. Raja Grafindo Persada, 2003)

Doi, Rahman I., Penjelasan Lengkap HukumHukum Allah (Syariab) (Jakarta Utara: PT Raja Grafindo Persada, 2002).

Fathoni, Abdurrahmat, Metodologi Penelitian dan Teknik Penyusunan Skripsi (Jakarta: PT. Rineka, 2006).

Ghozali, Abdul Rahman, Fiqh Munakahat. (Jakarta: Kencana Media Group, 2003).

Hamka, Tafsir al-Ažbar (Yayasan Nurul Iman), juz II.

Harjono, Anwar, Hukum Islam Keluasan dan Keadilannya (Jakarta: PT. Bulan Bintang, 1987).

Mansyur, Abdil Qadir, Buku Pintar Fikith Wanita. (Jakarta: Dar al-Nashr, 2012).

Nasution, S., Metode Research (Penelitian Ilmiah). (Jakarta: Bumi Aksara, 2003).

Poerwadarninta, Kamus Umum Bahasa Indonesia. (Jakarta: Balai Pustaka, 1985).

Ramulyo, Mohammad Idris, Hukum Perkawinan Islam Suatu Analisis dari Undang-Undang No. 1 Tabun 1974 dan Kompilasi Hukum Islam. (Jakarta: PT Bumi Aksara, 2004).

Sabiq, Sayyid. 1980. Fikih Sunnah Jilid 6. (Bandung: PT. Al-Ma'arif, 1980).

Saebani, Beni Ahmad, Metode Penelitian, (Bandung: Pustaka Setia, 2008).

Saleh, Wantjik 1980. Hukum Perkawinan Indonesia (Jakarta Timur: Ghalia Indonesia, 1980).

Salim, Abdul Malik Kamal bin As-Sayyid Salim., Shabih Fikih Sunnah jilid 3 (Jakarta: Pustaka Azzam, 2009).

Shafra, Fikih Munakahat (Bukittinggi: STAIN Press, 2006).

Shomad, Abdul, Hukum Islam Penormaan Prinsip Syariah dalam Hukum Indonesia. (Jakarta: Kencana Prenada Media Group, 2012) 
Soimin, Soedaryo, Hukum Orang dan Keluarga. (Jakarta: Sinar Grafika, 1992).

Sudarsono, Hukum Kekeluargaan Nasional. (Jakarta: PT. Rineka Cipta, 1991).

Sukardi, Metodologi Penelitian Pendidikan. (Jakarta: Bumi Aksara, 2003).

Suma, Muhammad Amin, Hukum Keluarga Islam di Dunia Islam (Jakarta: PT Raja Grafindo Persada, 2000).

Sumitro, Warkum, Dasar-Dasar Memahami Hukum Islam di Indonesia, (Surabaya: Karya Anda, 1994).

Syarifuddin, Amir, Hukum Perkawinan Islam di Indonesia Antara Fiqh Munakabat dan Undang-Undang Perkawinan (Jakarta: Kencana Prenada Media Croup, 2009).

Usman, Husaini dan Purnomo Setiady Akbar, Metodologi Penelitian Sosial (Bandung: Bumi Aksara, 2006).

\section{Jurnal}

Agustin, Asteria, Turnomo Rahardjo, and Taufik Suprihatini, "Manajemen Konflik Antarpribadi Pasangan Suami Istri Beda Agama", Interaksi Online, 1.2, 2013.

Ahmad, Baharuddin, "Nikah Beda Agama dalam Pandangan Liberalis dan Peraturan Perkawinan Indonesia", Al-Risalah, 12.1, 2012.

Ashsubli, Muhammad, "Undang-Undang Perkawinan dalam Pluralitas Hukum Agama (Judicial Review Pasal Perkawinan Beda Agama)", Jurnal Cita Hukum, 3.2, 2015.

Hutapea, Bonar, "Dinamika Penyesuaian Suami-Istri dalam Perkawinan Berbeda Agama (the Dynamics of Marital Adjustment in the Interfaith Marriage)", Sosiokonsepsia: Jurnal Penelitian dan Pengembangan Kesejabteraan Sosial, 16.01, 2011.

Jamil, M. Mukhsin, "Revitalisasi Islam Kultural", Walisongo: Jurnal Penelitian Sosial Keagamaan, 21.2, 2013.

Mallarangan, Hilal, "Pembaruan Hukum Islam dalam Hukum Keluarga di
Indonesia", Hunafa: Jurnal Studia Islamika, 5.1, 2008.

Nofiardi, Nofiardi, and Syafwan Rozi, "Penerapan Nilai Toleransi Antar Budaya dalam Pelaksanaan Hukum Kewarisan Islam pada Masyarakat Perbatasan di Rao Pasaman Sumatera Barat", Ijtihad: Jumal Wacana Hukum Islam dan Kemanusiaan, 17.1, 2017.

Palandi, Anggreini Carolina, "Analisa Yuridis Perkawinan Beda Agama di Indonesia", Lex Privatum, 1.2, 2013.

Rahman, Yusuf, "Pengantar Redaksi", Journal OfQur'an And Hadith Studies, 1.1, 2012.

Rahmaniah, Syarifah Ema, "Multikulturalisme dan Hegemoni Politik Pernikahan Endogami: Implikasi dalam Dakwah Islam", Walisongo: Jurnal Penelitian Sosial Keagamaan, 22. 2, 2014.

Sembiring, Elsaninta, dan Vanny Christina, "Kedudukan Hukum Perkawinan Adat Di Dalam Sistem Hukum Perkawinan Nasional Menurut UU No. 1 Tahun 1974", Parental, 1.4, 2014.

Syahr, Zulfia Hanum Alfi, "Wasiat Wajibah sebagai Wujud Penyelesaian Perkara Waris Beda Agama dalam Perkembangan Sosial Masyarakat", Holistik, 1.2, 2016.

Wahyuni, Sri, "Kontroversi Perkawinan Beda Agama di Indonesia", Jurnal Hukum Islam IAIN Pekalongan, 13.1, 2011.

-----, "Perkawinan Beda Agama dalam Perspektif Agama-agama", Jurnal Essensia, 3, 2, 2005.

------, "Politik Hukum Perkawinan dan Perkawinan Beda Agama di Indonesia", Jurnal Pusaka, 1.2, 2014.

Zada, Khamami, "Arus Utama Perdebatan Hukum Perkawinan Beda Agama", Abkam: Jurnal Ilmu Syariah, 13.1, 2013. 